\title{
Putting Theory into Practice: An Examination of Preservice Teachers' Beliefs about Teaching Science
}

\author{
Tracy M. Walker, Trina Spencer, Shandra Claiborne-Payton, Leslie Whiteman \\ College of Education Virginia State University, College of Natural and Health Sciences \\ USA
}

\begin{abstract}
Given the widening achievement gap for minorities in science, there is a critical need to increase the numbers of highly qualified teachers from underrepresented groups to nurture the nation's diverse populations. Therefore, Virginia State University's College of Education designed field-based experiences incorporating applied knowledge, practices, and hands-on learning by exposing preservice teachers to the application of science concepts. To measure preservice teacher self-efficacy, the Teaching Science as Inquiry instrument was administered at the beginning and end of the semester in which preservice teachers participated in field-based experiences. Significant results were found in areas relating to the constructs of personal self-efficacy (creating explanations from data, construct explanations from observations, and confidence in their skills to obtain scientific evidence) and outcome expectancy (defend newly acquired knowledge, make results of investigations public, and creating investigations for students). Significant improvement in some self-ratings suggests preservice teachers were successful in incorporating applied knowledge and hands-on learning experiences. The study's broader impact is that minority elementary preservice teachers, who are likely to teach minority children, are better prepared to face the challenges of teaching science. Ultimately, this will contribute to the "grade school to grad school" pipeline to increase the number of minority students who pursue science careers.
\end{abstract}

\section{Introduction}

Research shows that social, psychological and cultural factors greatly influence students' motivation and ability to learn [23, 27]. Student performance and achievement, especially in STEM areas, are tied to their motivational beliefs (e.g., selfefficacy) and availability of positive racial/ethnic role models [5, 15]. Negative attitudes of students can be changed by exposing elementary students of either gender to positive experiences in science [17]. Information that could enrich the traditional curriculum could be extremely beneficial to teacher preparation programs, departments of education, and professionals in the field of science education that seek to enhance minority student performance. Preparing quality teachers to teach science in the classroom is a complex process. Leaders of colleges and universities are accountable for ensuring that teachers have the skills needed before graduating them from their program [9]. Yet, debates exist regarding the best way to prepare teachers to ensure better student outcomes.

Teaching is the involvement of complex processes that require understanding in a larger scope [20]. It pertains to teachers' capabilities to synthesize and integrate this knowledge in various situations, different conditions, and wide diversity of participants [20]. Moreover, Hollins posited that quality teaching involves provision of equitable access and opportunity to extend learners' current knowledge by integrating the ability to construct and develop new knowledge. With these definitions, it can be assumed that most of the research on the field of education focused on the importance of teaching in developing academic outcomes.

However, there have been concerns about the science competence of teachers. The early study of [11] pioneered the research on the development of competence as related to the process of skills acquisition. Dreyfus and Dreyfus asserted that individuals acquire skills through instruction, experience, and modeling. In addition, through this experiential learning, individuals acquire the ability to produce intuitive responses in complex situations. It was also found that the development of competence is a lifelong challenge that includes shifts in which individuals pass through different stages as they develop competence.

\section{Science Teaching and Confidence}

Wenner [34] found that low levels of science content knowledge correlated with a lack of confidence towards teaching science among preservice teachers. This study recommended integration of science content and methods courses, increased science requirements in the curriculum, and an emphasis of hands-on laboratory procedures. 
According to Watters and Ginns [33], negative feelings and attitudes about science may relate to preservice teachers' own K-12 experiences. Teachers disinterested in science tend to pass that attitude on to the students. Interest is tied to motivation, which in turn determines how much effort a person will devote to learning a topic [10].

It is critical that teacher preparation programs address preservice teachers' negative dispositions toward science. Student performance and achievement, especially in STEM areas, are also often found to be related to motivational beliefs (such as self-efficacy) and accessibility to positive role models [5, 15]. Further, Jarrett [21] found that the best predictor of interest and confidence in teaching science for preservice teachers is a positive experience with science in elementary school.

Jarrett's study underscores the importance of a positive experience with science for elementary school children. Research also shows that teacher quality has an impact on student learning; if teachers do not know the STEM content or how to teach it, then most students will not learn it [22]. Future teachers who were taught "little and poorly" as children become teachers who teach "little and poorly" [18].

Among many factors that impact student outcomes, the greatest influence is the quality of teachers and their instructional practices [2]. Barber and Mourshed [2] described the teacher as the main driver of the variation in student learning in school, and claimed that students who were not exposed to high-caliber teachers in the early grade levels demonstrated slow academic progress and were less likely to make up for the lost years. Moreover, teachers become the standards of an educational system's quality - and the latter cannot exceed the former. Only through bettering teacher science instruction can outcomes be improved; universally high outcomes can only be achieved if the proper mechanisms that ensure the delivery of high-quality science instruction are in place [2].

The importance of adequate teacher training and clinical practice is further emphasized by the existing literature, contending that teachers with more training and a stronger professional background are more highly rated and effective than those without $[8,14,16]$.

\subsection{Science Teaching and Underrepresented Populations}

Expanding Underrepresented Minority Participation, a 2011 publication developed jointly by the National Academy of Sciences, the National Academy of Engineering, and the Institute of Medicine, upheld that by the time children reach kindergarten, they have already developed the necessary "habits of mind" to be successful in science [24]. However, the study also maintains that as these students progress through $\mathrm{K}-12$, their confidence and interest in science tended to decrease. For minority students in particular, the problem is amplified:

"Even if students are prepared, have adequate information, and are ambitious and talented enough to succeed in science, success may also hinge on the extent to which students feel socially and intellectually integrated into their academic program" [24].

Schools must combat false impressions of science as a foreign, unwelcoming entity. This attention to helping students develop positive attitudes toward science needs to start in the early grades. In an elementary school workforce where the typical science teacher is female, white, and over the age of 40 [12], it can be easy for minority students to feel isolated.

Therefore, programs intended to address the widening achievement gap for minorities must focus not only on preparing aspiring scientists, but also on preparing qualified minority preservice K-6 teachers. Research demonstrates that teachers exposed to a two-year professional development program to design, implement, and revise problem-based, interdisciplinary curricula demonstrated enhanced self-efficacy and use of reform-based classroom practices [13]. Reform-based practices include inquiry-based, hands-on, cooperative, and problembased teaching for depth of student understanding. Interdisciplinary team projects can also enhance students' personal growth, including confidence, independence, tolerance, leadership, collaborative skills, and sense of belonging [3].

It is necessary for teacher education programs to implement effective strategies and meaningful experiences to ensure that teachers have a fair chance of effectiveness when they enter the classroom [7]. Educators must constantly monitor and manage these experiences to ensure that the curriculum involves every aspect beneficial to the preservice teacher candidate.

\subsection{Science Teaching and Experiences}

Appleton and Kindt [1] found that beginning teachers are often prone to undertake safe activities first (e.g., activities with predictable outcomes and/or drawn from personal experience or that of colleagues). Therefore, if such individuals have experienced science largely in the forms of book research and memorization in their own schooling, they will tend to see these activities as safe and effective. In comparison, those individuals exposed to the excitement of hands-on inquiry-based science activities would likely see these activities as safe and 
effective. A recommendation from the Appleton and Kindt study [1] is that preservice teacher education preparation should focus on providing students with a repertoire of activity ideas that develop science pedagogical content knowledge.

Thus, this study sought to examine the interest and confidence of preservice K-6 teachers in teaching science content as a result of the integration of instructional best practices in teaching and research in their curriculum methods courses to enhance their content knowledge, pedagogical skills and positive dispositions.

\section{Methods}

This paper identifies one component of a larger research project (funded through the National Science Foundation HBCU-UP Targeted Infusion Project) which sought to expand pre-service teacher's science pedagogical knowledge and expertise. During the fall 2015 semester, pre-service teachers participated in coordinated field experiences implemented by a team of interdisciplinary faculty across three methods courses (English/literacy, science, and curriculum methods). These field experiences, intended to instruct education students as 'true' biology students, included an Appomattox River research project, a fall science exploration day, and membership and attendance in VAST (Virginia Association of Science Teachers).

\subsection{Science Processing Skills Coursework}

The goal of the science methods course was to provide science pedagogical content knowledge. Although students take 12 credit hours of science during this program, time limitations did not allow the instructor to address specific gaps in science content knowledge during this one-semester course. It is well accepted that relevant coursework in science and teacher content knowledge is a strong indicator in predicting science achievement of their students [28]. If teachers themselves do not know STEM content, then their students will not learn it [22].

The science content discussed in this methods course was broad and encompassed physical, chemical and biological science. Preservice teachers were given the tools to identify and remediate specific areas of science content weakness. At the beginning of the semester, the preservice teachers were given a science content assessment based on fifth-grade Virginia Standards of Learning (SOL) science test release items. As a follow-up activity, preservice teachers registered for and explored the resources on the National Science Teacher Association (NSTA) Learning Center [26]. They were advised to complete the professional development indexers to diagnose specific science content needs and remediate areas of weakness using SciPacks.

At the start of the semester, preservice teachers were provided with the Virginia Initiative for Science Teaching and Achievement (VISTA) definition of hands-on learning as "students purposefully manipulating real science materials when safe and appropriate in a way similar to a scientist" [31], and inquiry as the "careful and systematic method of asking questions and seeking explanations" [32]. The National Science Education Standards (NSES) model of the essential five features of inquiry in the classroom was utilized as a guideline for development of inquiry activities [25]. NSES believes that "students who engage in science inquiry demonstrate an ability to describe objects, ask questions, communicate ideas to others, and construct explanations" [30].

Instruction then kicked off with a pendulum inquiry experiment in which preservice teachers were given one of two investigative questions: What is the effect of string length on the period of a pendulum? What is the effect of bob mass on the period of a pendulum? Working in teams of four, they were challenged to propose a hypothesis and then develop the experimental design that would test the effect of string length and mass on the period of the pendulum. Assistance provided by the instructor was intentionally limited to allow the preservice teachers to brainstorm ideas. The experimental design was an enormous challenge because their only prior experience with science had primarily been following "cookbook labs". These very prescriptive labs teach basic skills, such as using scientific equipment, measuring, observing, inferring, etc., but they rarely support inductive reasoning, inquiry or the authentic nature of science [19].

The preservice teachers were further challenged to determine the type of data needed to address their hypothesis, analyzing their data beyond superficial observations, and making relevant conclusions. Initially, class discussions were limited to "my results support my hypothesis" or "my results do not support my hypothesis". They struggled with understanding the significance of their results and were obsessed with knowing whether their results or answers are "right or wrong".

Figure 1. Cookbook Lab to Inquiry Lab [35]

Example Cookbook Lab - Static Electricity

Background: Rubbing a balloon creates a buildup of negatively-charged electrons on the surface called static electricity. Electrons can pull very light positively-charged items toward them. Specific procedure:

1. Place an empty aluminum can on its side on a 
table.

2. Blown up balloon and rub back and forth through your hair really fast.

3. Hold the balloon close to the can without actually touching the can. Static electricity will roll the can towards the balloon.

4. Measure and record the distance moved in millimeters.

Example Inquiry Lab - Static Electricity Demonstrate the cookbook lab to students during the anticipatory set to promote student-directed development of investigative questions.

Potential investigative questions that might be developed by students:

- What effect does balloon size have on the power of the pull?

- Are there materials other than hair that cause static electricity?

- Will all types of hair cause static electricity?

- Will the balloon pull all types of cans?

- Will the balloon pull other items?

- How strong is the pull of the balloon?

- Can water be added to the can? How much water until the balloon can't pull it anymore?

Materials:

- Assortment of materials to test for developing static electricity: wool, cotton and other fabric materials; human and artificial hair

- Assortment of materials to test the strength of the pull: cans of different sizes and materials, packing peanuts, tissue paper, etc.

- Water

\section{Directions:}

1. Design and conduct an experiment to answer your investigative question.

2. Be mindful all the class safe laboratory procedures.

3. Record the data in a manner that allows you to share with the class.

In a follow up activity, the preservice teachers were randomly given existing cookbook lab exercises and tasked with converting them into inquiry, student-centered activities following the method of Corder and Slykhuis [6], i.e., replace, retain and modify, and remove. The preservice teachers replaced standard introductory descriptions and background information with investigative questions. The class definition of an effective investigative question was one that has something to measure and/or compare. Next, they modified the procedure by simplifying the directions, but retained the investigative parameters and safety guidelines.
Finally, they removed the results tables to allow their future students to create their own methods for organizing data. For each converted lab, the preservice teachers had to anticipate their students' potential responses by developing procedures for each investigative question and data tables for the results. Figure 1 is an example converted lab. The preservice teachers seemed to appreciate learning that developing inquiry labs from existing lab procedures need not be complicated or intimidating.

\subsection{Field-based Experiences}

In addition to the Science Processing Skills course, the preservice teachers participated in several field-based experiences enabling them to better understand the practical aspects of the formal instruction. These activities included an Appomattox River Project, visits to area museums and institutes, and membership in a state-level professional organization. The intent of the Appomattox River Project was to analyze water quality and evaluate its impact on a variety of organisms that live in the environment surrounding the river. Students were required to monitor changes in chemical properties of the water and the impact on a variety of organisms that live in the environment, physical properties of the water, and the subsequent effects on the local microorganisms, invertebrates, plants and animals. Non-science majors at Virginia State University (VSU), including preservice elementary education teachers, do not typically enroll in the BIOL 121 course; this course is specific to biology majors. Instead, the non-science majors enroll in BIOL 427 Science Process Skills methods course. In addition to the Appomattox River Project, preservice teachers participated in Science Exploration Day during the fall 2015 semester. This activity was provided for local fourth and fifth grade elementary students. Preservice elementary education teachers, supervised by Biology and Education faculty, led students in inquiry-based, hands-on science lessons developed during their enrollment in the three methods classes.

Finally, while professional development is important in any field, it is especially essential for teachers to keep up-to-date on new research on how children learn, emerging technology tools for the classroom, and new curriculum resources. Preservice teachers enrolled in the BIOL 427 methods course were provided with information on how to get started in a career as a science educator and improve professionally over time. One mandatory requirement for the BIOL 427 students was membership in the Virginia Association of Science Teachers (VAST).

For most VSU students, this was their first opportunity to network with other science educators and preservice teachers from across the state and country. Our preservice teachers benefited from 
learning how in-service teachers plan, implement and assess the Virginia Standards of Learning with innovative teaching strategies. Participation in this (and other) professional development conferences allowed students to disseminate the project results, including effective lesson plans and teaching strategies. All preservice teachers that participated in the activities were also required to present at VAST.

Additional professional development activities for preservice teachers included field experiences such as area museums and institutes (the Virginia Science Museum and the Virginia Mathematics and Science Coalition) to learn how to effectively incorporate such resources into an interdisciplinary science education unit. These experiences were intended to ensure the pre-service teachers were engaged in 'real-life' science activities.

\subsection{Teaching Science as Inquiry Instrument}

This project focuses on one aspect of the overall project: an examination of the pre-services teachers' self-efficacy through use of the Teaching Science as Inquiry (TSI) instrument [29]. The Teaching Science as Inquiry (TSI) instrument is a validated tool intended to measure teacher interest and confidence [29]. The TSI instrument is a 69 item Likert-scale survey using ratings from 1 (Strongly Disagree) to 5 (Strongly Agree).

The TSI instrument was designed to focus on "the two dimensions of self-efficacy described by Bandura (1977), personal self-efficacy and outcome expectancy" [29]. Bandura's theory of social learning helps us examine the construct of personal science teaching using a cognitive science perspective. His theory advances that individuals are motivated to perform an action when they believe this action will have positive results. Self -efficacy is often used in everyday terms, when we feel confident to do something. Examples include the capability to get a job done or think of the best ideas for a plan. Therefore, teachers who have high personal science teaching self-efficacy will demonstrate that they can effectively teach science.

For the purpose of the TSI, personal self-efficacy was defined as one owns conclusion about their ability to perform in a specific situation. Outcome expectancy was defined as one owns conclusion about the potential outcomes of the specified actions. The instrument consisted of 34 personal self-efficacy items and 35 outcome expectancy items. Internal consistency measures were reported by the instrument developers as meeting an acceptable level for a first-generation instrument [29].

Therefore, the TSI survey was selected to assist in determining if preservice teachers enrolled in a science methods courses experienced any changes in their beliefs about their science teaching after participating in problem-based learning activities and field experiences.

The survey was administered as a pre-test (August) and post-test (December) during the fall 2015 semester in which the pre-service teachers participated in the integrated science activities. The over-arching question to be answered by this component of the grant project was: Does preservice teacher self-efficacy and knowledge for teaching science change as a result of participating in integrated science field experiences? The findings could provide further information as to whether a change in the way in which science is taught influences pre-service teachers' self-efficacy. Participants were asked to complete the TSI survey through Qualtrics, an online survey management system, in August 2015 and December 2015 of the fall methods course. Data was then downloaded from Qualtrics to the IBM Statistical Package for the Social Sciences 22 (IBM SPSS 22) for analysis. Analyses included frequencies, descriptive statistics, and a paired samples t-test to examine the differences in score means from the pre-test to the post-test.

\subsection{Background of the Preservice Teacher Participants}

Teacher candidates in the College of Education are required to pass all of the required licensure assessments for the state of Virginia prior to their student teaching experience. Elementary education teacher candidates are required to pass three assessments: Praxis 1: Mathematics, the Virginia Communication Literacy Assessment (VCLA), and the Reading for Virginia Educators Assessment (RVE). The Praxis 1: Math (730) test is a fortyquestion multiple choice test that measures the following skills: number and number sense, algebra, geometry and measurement, data analysis and probability. Praxis 2: Elementary Education: Content Knowledge focuses on the teacher candidates' understanding of the four major subject groups (math, science, social studies, and reading/language arts).

The VCLA contains 80 multiple choice items that are designed to measure communication and literacy skills. The RVE is designed to measure the preservice teacher candidates' knowledge of the effective components for reading instruction. Passing Praxis 1 math with a minimum score of 178 and the VCLA with a minimum score of 470 are both required before entering the teacher education program. To obtain teacher licensure in the state of Virginia, the VCLA, RVE, and Praxis 2 must be taken with passing results.

In addition to passing the required assessments, most students will have completed 12 hours of science, 12 hours of mathematics and a 3 hours 
course in instructional technology prior to enrolling in the methods classes discussed in this proposal. Elementary education teacher candidates at Virginia State are required to pass the prerequisite laboratorybased STEM courses with an average grade of "C" or better. Although these candidates routinely perform well enough on the Praxis II to pass, they consistently perform lower on Praxis II math and science content questions than on reading/language arts and social studies content questions.

According to the results of a recent survey, most preservice elementary teachers at Virginia State University felt they possess the necessary training and self-confidence to teach science in the elementary classroom. However, the same survey revealed that over $70 \%$ of the same group would prefer not to teach science as compared to other subjects. When encouraged to reference their own experiences, students' memories were mainly negative; this is particularly true of their experiences in high school and college.

\section{Results}

Frequency analyses and descriptive statistics were first calculated for the TSI results from the fall 2015 semester. All pre-service teachers were invited, and provided consent to participate in the survey administration ( $n=10$, pretest; $n=9$, posttest). In general, preservice teachers' responses from the pretest to the post-test administration of the Teaching Science as Inquiry (TSI) survey did slightly vary; however, not enough to be significantly different in most areas. Responses for the pre-test ranged from disagree to agree, although for the post-test, their responses ranged more frequently in the "agree" category which included responses of 'agree' and strongly agree'. A comparison of means test was then conducted to determine if any statistical differences were indicated for the preservice teachers' responses from the pre- to the post-test. An independent samples t-test was conducted since responses were from the same pool of participants (one group) and contained two means (pre-test scores and post-test scores).

\subsection{Results of Independent Samples $t$-test}

Results of the independent samples $t$-test were significant for 6 of the 69 survey items (Table 1): $\# 1-(t(19)=-2.248, p=.037) ; \# 2-(t(19)=-2.192$, $p=.041) ; \# 5-(t(19)=-2.676 p=.015) ; \# 6-(t(19)$ $=-3.839, p=.001) ; \# 9-(t(19)=-4.28, p=.000)$; and \#13 - $(t(19)=2.125, p=.047)$ (see Table 1). The remaining 63 survey items provided nonsignificant results. Of interest is Item \#13 in which there was a sharp decrease from the pretest $(\mathrm{M}=$ $4.40, \mathrm{SD}=.52)$ to posttest $(\mathrm{M}=3.91, \mathrm{SD}=.54)$ administration.
Table 1. Results of Independent Samples $t$-test

\begin{tabular}{|c|c|c|c|c|}
\hline$\#$ & Survey Item Statement & $t$ & $\mathrm{df}$ & Sig. \\
\hline 1 & $\begin{array}{l}\text { I will be able to offer } \\
\text { multiple suggestions for } \\
\text { creating explanations } \\
\text { from data. } \\
\text { (construct: self-efficacy) }\end{array}$ & -2.25 & 19 & 0.037 \\
\hline 2 & $\begin{array}{l}\text { I will be able to provide } \\
\text { students with the } \\
\text { opportunity to construct } \\
\text { alternative explanations } \\
\text { for the same } \\
\text { observations. } \\
\text { (construct: self-efficacy) }\end{array}$ & -2.19 & 19 & 0.041 \\
\hline 5 & $\begin{array}{l}\text { I have the necessary } \\
\text { skills to determine the } \\
\text { best manner through } \\
\text { which children can } \\
\text { obtain scientific } \\
\text { evidence. } \\
\text { (construct: self-efficacy) }\end{array}$ & -2.68 & 19 & 0.015 \\
\hline 6 & $\begin{array}{l}\text { I will require students } \\
\text { to defend their newly } \\
\text { acquired knowledge } \\
\text { during large and/or } \\
\text { small } \\
\text { discussions. } \\
\text { (construct: } \\
\text { expectancy) }\end{array}$ & -3.84 & 19 & 0.001 \\
\hline 9 & $\begin{array}{l}\text { I will expect my } \\
\text { students to make the } \\
\text { results of their } \\
\text { investigations public. } \\
\text { (construct: outcome } \\
\text { expectancy) }\end{array}$ & -4.28 & 19 & 0.000 \\
\hline 13 & $\begin{array}{l}\text { I will create (plan) } \\
\text { investigations through } \\
\text { which students will be } \\
\text { expected to gather } \\
\text { particular evidence. } \\
\text { (construct: outcome } \\
\text { expectancy) }\end{array}$ & 2.13 & 19 & 0.047 \\
\hline
\end{tabular}

\subsection{Results of Effect Size Calculations}

For the same six significant items, effect sizes $(r)$ were also calculated (Table 2). Threshold estimates for interpreting effect size for $r$ ranges from .10 for small, .30 for medium, .50 for large, and .70 for a very large effect [4]. For significant items 1, 2, and 13, the effect size calculations demonstrate a medium to large effect. Item 9 approaches an effect size of medium. The final two significant items, 5 and 6 , demonstrate effect sizes approaching very large. Item 9 demonstrated a moderate effect size and was the lowest of the six statistically significant items. 
Table 2. Effect Size Calculations

\begin{tabular}{llll}
\hline$\#$ & Survey Item Statement & $r$ \\
\hline 1 & $\begin{array}{l}\text { I will be able to offer multiple } \\
\text { suggestions for creating explanations } \\
\text { from data. } \\
\text { (construct: self-efficacy) }\end{array}$ & \\
\hline 2 & $\begin{array}{l}\text { I will be able to provide students with } \\
\text { the opportunity to construct alternative }\end{array}$ & 0.42 \\
explanations for the same observations. \\
(construct: self-efficacy)
\end{tabular}

\section{Discussion}

Overall, pre-service teachers' perceptions about their ability to teach science varied slightly over 69 survey items. However, these slight variations only proved to be statistically significant for six of the Likert items (\#1, 2, 5, 6, 9, and 13). Three of these items $(1,2$, and 5) were developed to be related to the construct of personal self-efficacy. The original development of the TSI instrument intended items 1 and 2 further related to the preservice teacher's confidence for formulating explanations from evidence. Item 5 was developed to identify the preservice teacher's ability to give priority to evidence in responding to questions.

The statistically significant differences in these three items from the pre-test to the post-test administration of the instrument indicate increases in the preservice teachers' personal self-efficacy. These differences offer that participation in the integrated methods coursework activities, including embedded field experiences, helped the preservice teacher to become additionally self-assured of: 1) being able to offer multiple suggestions for creating explanations from data; 2) providing students with alternate explanations for observations; and 3 ) having the necessary skills to determine how to best manner in which to demonstrate to their students how to obtain scientific evidence.

The three significant items for outcome expectancy were for \#6, 9, and 13. Items 6 and 9 focused on the concept of the learner being able to effectively communicate and justify explanations to their students. Item 13 focused on the learner giving priority to evidence when responding to questions from students. These statistically significant items specifically asked the preservice teacher to identify to what degree they would require their students to either present or defend their findings or data in small or large group or discussion, or make their results public. Of specific interest is item \#13 in which there was a marked decrease in level of agreement from the pretest to posttest. This particular item identified that at the beginning of the semester, the preservice teachers felt more confident in their ability to carry out or plan investigations for students to gather specific evidence than they did by the end of the semester methods courses.

\section{Recommendations}

\subsection{Recommendations for Practitioners}

Providing a structured field experience in at least one elementary school for preservice teachers to observe veteran teachers putting theory into practice is highly recommended. They need to see how science instruction is implemented throughout a variety of classroom settings. The veteran teachers can provide them the support, resources, and supervision they need to become successful.

Additionally, preservice elementary teachers should be required to implement activities learned in the science methods course with their own elementary school students as a method for reinforcing the 'teach the teacher' model of the fieldbased experiences. Such activities should require them to create lessons plans, select materials, and write a reflective statement after teacher. Reflection helps them discuss their strengths, areas of improvement, and allows them to develop higherlevel thinking and problem solving. These experiences help better prepare future teachers to handle the complex realities of our schools, classrooms, and studies.

\subsection{Recommendations for Further Research}

Recommendations for further research in this area should focus on explorations of the individual embedded field experiences in relation to selfefficacy and outcome expectancy in order to identify specific components in the field experiences that may have more of an impact. Further examination of the potential impacts on teacher preparation 
programs' ability to adequately prepare and increase the number of underrepresented science teachers is needed.

Disparities in educational opportunities pose a clear challenge to the American educational system; despite sporadic improvements in certain areas, the outlook for minority students in STEM areas remains grim. Research that could help reverse this problem is of critical importance. In addition, preservice teachers should be provided opportunities for inclusion in 'real-life' science experiences in order to potentially increase confidence for teaching science. It is critical, therefore, to not only familiarize minority students with the sciences and impart pertinent information, but also to root out false impressions of STEM subjects as foreign entities.

\section{Conclusion}

The preservice teachers in this project participated in a science methods course that was designed to nurture their confidence and interest for science teaching. This course emphasized the using the best practices for teaching science. The focus of this project was to better understand preservice teachers' perceptions of science teaching. Embedded field experiences were included in the fall 2015 semester in which the Teaching Science as Inquiry instruction was administered to determine any relationship between interactive science activities and personal self-efficacy and outcome expectancy.

The research question guiding this project asked Does pre-service teacher self-efficacy and knowledge for teaching science change as a result of participating in integrated science field experiences? Overall, an examination of responses to the 69 Likert-item instrument demonstrated some minor variation from pre-test to post-test responses; however, only six survey items demonstrated a difference large enough to be statistically significant. Three of the significant items were related to the concept of personal self-efficacy and the other three were related to outcome expectancy. Effect size estimates for the same six significant items ranged from medium to very large.

\section{References}

[1] Appleton, K and Kindt, I. (2002). Beginning elementary teachers' development as teachers of science. Journal of Science Teacher Education. 13(1), 43 - 61.

[2] Barber, M., and Mourshed, M. (2007). How the world's best-performing school systems come out on top. Mckinsey \& Company.

http://mckinseyonsociety.com/downloads/reports/

Education/Worlds_School_Systems_Final.pdf (6 February, 2010).
[3] Boyer, S., and Bishop, P. (2004). Young adolescent voices: Students' perceptions of interdisciplinary teaming. Research in Middle Level Education Online, 28(1), 73-76.

[4] Cohen, J. (1988). Statistical power analysis for the behavioral sciences. Hillsdale, NJ: Erlbaum.

[5] Cokley, K. (2003). What do we know about the academic motivation of African American college students? Challenging the "anti-intellectual myth" Harvard Educational Review 73, 524-558.

[6] Corder, G. and Slykhuis, J. (2011). Shifting to an inquiry-based experience. Science and Children, 48(9), 60-63.

[7] Darling-Hammond, L. (2010a). Evaluating teacher effectiveness. Center for American Progress. http://www.americanprogress.org/wpcontent/uploads/issues/2010/10/pdf/teacher_effectiveness. pdf (14, March 2010).

[8] Darling-Hammond, L. (2010b). Recruiting and retaining teachers: Turning around the race to the bottom in high-need schools. Journal of Curriculum and Instruction, 4(1). doi:10.3776/joci.2010.v4n1p16-32

[9] Darling-Hammond, L. (2010c). Teacher education and the American future. Journal of Teacher Education, 61(12), 35-47.

[10] Dewey, J. (1979). Interest and effort in education. In J.A. Boydston (Ed.), The middle works, 1899-1924: Vol. 7. 1912-1914 (pp. 153-197). Carbondale, IL: Southern Illinois University Press.

[11] Dreyfus, H., and Dreyfus, S. (1986). Mind over machines. New York: The Free Press.

[12] Fulp, S. L. (2002). 2000 National survey of science and mathematics education, National Science Foundation. Status of Elementary School Science Teaching. Chapel Hill, NC: Horizon Research, Inc.

[13] Haney, J. J., Wang, J., Keil, C., and Zoffel, J. (2007). Enhancing teachers' beliefs and practices through problem-based learning focused on pertinent issues of environmental health sciences. The Journal of Environmental Education, 38(4), 25-33.

[14] Hanushek, E. A. (2011). The economic value of higher teacher quality. Economics of Education Review, 466-479.

[15] Harris, A. L., and Marsh, K. (2010). Is a raceless identity an effective strategy for academic success among Blacks. Social Science Quarterly, 91, 1242-1263.

[16] Harris, D. N., and Sass, T. R. (2011). Teacher training, teacher quality and student achievement. Journal of Public Economics, 798-812.

[17] Harty, H., Beall, D., and Scharmann, L. (1985). Relationships between elementary students' science achievement and their attitudes toward science, interest in 
science, reactive curiosity, and scholastic aptitude. School Science and Mathematics, 85(6), 472-479.

[18] Hawkins, D. (1990). Defining and bridging the gap. In E. Duckworth, J. Easley, D. Hawkins, and A. Henriques (Eds.), Science education: A minds-on approach for the elementary years (pp. 97-139). Hillsdale, NJ: Lawrence Erlbaum Associates.

[19] Herron, S. S. (2009). Cookbook to collaborative: Transforming a university biology laboratory course. American Biology Teacher, 71, 548-552.

[20] Hollins, E. R. (2011). Teacher preparation for quality teaching. Journal of Teacher Education, 62(4), 395-407.

[21] Jarrett, Olga S. (1999). Science interest and confidence among preservice elementary teachers. Journal of Elementary Science Education, 11(1), 47-57.

[22] Jolly, E. J., Campbell, P. B., and Perlmann, Lesley. (2004). Engagement, capacity and continuity: A trilogy for student success. GE Foundation. http://www.campbellkibler.com/trilogy.pdf. (5 March, 2012).

[23] Kim, M., and Conrad, C. F. (2006). The impact of historically black colleges and universities on the academic success of African American students. Research in Higher Education 47, 399-427.

[24] National Academy of Sciences, National Academy of Engineering, and Institute of Medicine. (2011). Expanding underrepresented minority participation: America's science and technology talent at the crossroads. Washington, DC: National Academies Press. https://grants.nih.gov/training/minority_participation.pdf.

(27 December, 2016).

[25] National Research Council (2000). Inquiry and the National Science Education Standards: A guide for teaching and learning. Washington, DC: National Academy Press.

[26] National Science Teacher Association (NSTA). Learning center. http://learningcenter.nsta.org/ (2, September 2017).

[27] Palmer, R., and Gasman, M. (2008). "It takes a village to raise a child": The role of social capital in promoting academic success for African American men at a Black college. Journal of College Student Development, 49, 5270 .

[28] Rice, J. K. (2003). Teacher quality: Understanding the effectiveness of teacher attributes. Economic Policy Institute. Washington, DC.

[29] Smollock, L.D., Zembal-Saul, and Yoder, E.P. (2006). The development and validation of an instrument to measure preservice teachers' self-efficacy in regard to the teaching of science as inquiry. Journal of Science Teacher Education, 17, 137 - 163. DOI: 10.1007/s10972-0069015-6.
[30] Spencer, T. and Walker, T. (2011). Creating a love for science for elementary students through inquiry-based learning. Journal of Virginia Science Education, 4(2), 18 -25 .

[31] Sterling, D. R. (2013). How does leadership matter? Developing and teaching a definition of hands-on science, a prerequisite for effective inquiry teaching. The Journal of Mathematics and Science, 13, 79-92.

[32] Sterling, D. R. (2014) How to develop a problembased science unit manual. Virginia Initiative for Science Teaching and Achievement (VISTA). http://physics.gmu.edu/ hgeller/vistaPBL.pdf. (21, August 2017).

[33] Watters, J. J. and Ginns, I. S. (2000b). Developing motivation to teach elementary science: Effect of collaborative and authentic learning practices in preservice education. Journal of Science Teacher Education, 11(4), 301-321.

[34] Wenner, G. (1993). Relationship between science knowledge levels and beliefs toward science instruction held by preservice elementary teachers. Journal of Science Education and Technology, 2(3), 461-468.

[35] Whiteman, L., Walker, T. \& Spencer, T. (2014). Impact of a science methods course on preservice elementary teachers' knowledge and confidence of teaching with scientific inquiry and problem-based learning. The Journal of Mathematics and Science: Collaborative Explorations, 15, 33-52. 